\title{
PENINGKATAN DAYA IMUN KELUARGA MELALUI TOGA BERBASIS KEGIATAN PKK DESA KREBET
}

\author{
Nur Chayati ${ }^{1)}$, M. Fariez Kurniawan'2), Ambar Relawati'1) \\ 1)Magister Keperawatan, Pasca Sarjana, Universitas Muhammadiyah Yogyakarta, Bantul, \\ Daerah Istimewa Yogyakarta, Indonesia \\ 2)Program Studi Farmasi, Fakultas Kedokteran dan IImu Kesehatan, Universitas Muhammadiyah Yogyakarta, Bantul, \\ Daerah Istimewa Yogyakarta, Indonesia \\ Corresponding author : Nur Chayati \\ E-mail : nchayati1983@gmail.com
}

Diterima 02 September 2021, Direvisi 12 September 2021, Disetujui 12 September 2021

\begin{abstract}
ABSTRAK
Krebet adalah sentra industri batik kayu yang mempunyai potensi kepariwisataan baik dari sisi budaya maupun alamnya. Pemberdayaan kelompok PKK di desa Krebet sangat bermanfaat untuk meningkatkan ketahanan keluarga baik dari segi ekonomi, sosial, budaya maupun agama. Berbagai keterampilan yang diperoleh, akan bisa membekali anggotanya untuk bisa hidup lebih baik. Kondisi pandemi Covid sangat membutuhkan daya imun yang cukup kuat untuk bisa menangkal virus Covid- 19 . Hasil need assessment menunjukkan bahwa kelompok PKK memerlukan tambahan informasi tentang Toga. Toga termasuk tanaman yang murah dalam produksinya, tidak membutuhkan lahan yang luas, cocok ditanam baik di dataran rendah maupun tinggi, sudah dikenal masyarakat Indonesia serta cara pengolahan hasil produksi yang mudah untuk skala rumah tangga. Tujuan dari pengabdian masyarakat adalah mengenalkan tentang jenis Toga, manfaat Toga dan pengolahan Toga sederhana. Kegiatan pengabdian masyarakat diikuti oleh 14 peserta diawali pemberian pendidikan kesehatan tentang Toga dan manfaatnya, dan tatacara budidaya Toga. Kegiatan berikutnya adalah praktek mengolah jahe menjadi puding. Evaluasi berdasarkan kuesioner menunjukkan terjadi peningkatan pengetahuan peserta sebelum dan setelah pemberian pendidikan kesehatan.
\end{abstract}

Kata kunci: toga; desa wisata krebet; covid-19; pemberdayaan masyarakat; ketahanan keluarga

\section{ABSTRACT}

Krebet is the center of the wooden batik industry that has tourism potential both in terms of culture and nature. The main activities carried out by mothers are mostly housewives, and are involved in PKK social activities. The Covid-19 pandemic requires a strong immune system to be able to ward off the Covid-19 virus. The results of the assessment in the area, the agreed skill to be taught to PKK mothers is the cultivation of the Toga plant. Toga is a plant that is cheap to produce, does not require a large area of land, suitable for planting in both the lowlands and highlands, well known to the Indonesian people and an easy way of processing production for household scale. Empowerment of the PKK group is very useful for increasing family resilience in terms of economic, social, cultural and religious aspects. Various skills obtained will be able to equip its members to be able to live better. This community service activity was attended by 14 participants, carried out in three stages, namely providing health education about Toga and its benefits, as well as procedures for cultivating Toga. The third stage is the practice of how to process the Toga. The evaluation was carried out by giving a questionnaire of knowledge about Toga and skills in practicing how to process Toga results before and after the activity. The results of data analysis showed an increase in participants' knowledge before and after the provision of health education.

Keywords: toga; krebet tourism village; covid-19; community empowerment; family resilience

\begin{abstract}
PENDAHULUAN
Desa Krebet dikenal sebagai desa wisata batik kayu. Desa ini berlokasi di Pedukuhan Krebet, Desa Sendangsari JI Pajangan, Km. 4, Benyo, Sendangsari, Pajangan, Kabupaten Bantul, Daerah Istimewa Yogyakarta. Tepatnya sekitar $12 \mathrm{~km}$ barat daya kota Yogyakarta, bersebelahan dengan Goa
\end{abstract}

Slarong. Desa Krebet terdiri dari enam RT (1-6). Puskesmas terdekat dengan wilayah ini adalah Puskesmas Kapanewon dan Puskesmas Pajangan (Pemerintah Kabupaten Bantul, 2021). Desa Krebet terkenal akan keindahan alam, seni budaya dan pengrajin pahatan kayu ataupun batik kayu yang menjadi produk unggulan mata pencaharian masayarakat 
daerah ini (Kurniawan \& Sadali, 2018). Masyarakat Desa Krebet pada mulanya berprofesi sebagai petani dan peternak, seiring dengan berkembangnya kerajinan kayu di daerah ini sejak tahun 1970, sebagian besar masyarakat beralih profesi menjadi pengrajin batik kayu yang kini menjadi icon Desa Krebet, hingga merambah pada pengelolaan pariwisata alam desa. Tidak sedikit dari masyarakat membuka sanggar batik kayu ataupun bekerja sama dengan pemerintah daerah membuat serta mengelola wisata alami dan buatan seperti outbound, pehelatan budaya serta jelajah desa (Rahmawati \& Purwohandoyo, 2019).

Kerajinan kayu Desa Krebet dimulai sejak tahun 1972. Mulanya hanya dikerjakan oleh dua hingga tiga kepala keluarga saja, namun sejak 1990 berkembang pesat. Produk yang dihasilkan dari semula hanya topeng kayu berkembang menjadi wayang klithik, topeng kayu, peralatan rumah tangga, patung - patung hewan, loro blonyo, pigura bahkan meubel. Motif hasil produksipun berkembang dalam bentuk batik kayu. Saat ini di Desa Krebet memiliki kurang lebih 20 sanggar pengrajin yang dapat menyerap kurang lebih 350 tenaga kerja lokal. Hasil produk di pasarkan dengan cara membuka showroom di sanggar, juga dijual ke Yogya, Jakarta dan Bali (Choironi et al., 2019).

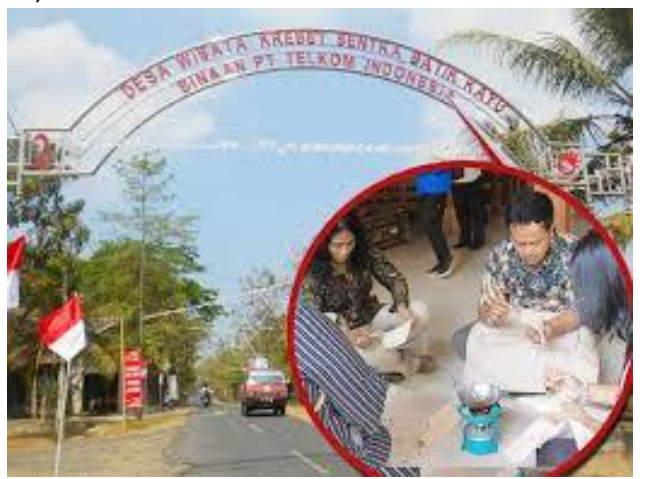

Gambar 1. Kondisi desa wisata Krebet (JoSS.co.id)

Krebet adalah sentra industri batik kayu yang mempunyai potensi kepariwisataan baik dari sisi budaya maupun alamnya. Wilayah Kecamatan Pajangan berada di daerah dataran rendah. Ibukota Kecamatan Pajangan berada pada ketinggian 100 meter diatas permukaan laut. Bentangan Wilayah Kecamatan Pajangan $100 \%$ berupa daerah yang berbukit sampai bergunung (Lolita et al., 2017). Kegiatan utama yang dilakukan penduduk laki-laki adalah sebagai pengrajin, dan pegawai. Untuk para istri lebih banyak sebagai ibu rumah tangga. Salah satu bentuk kegiatan yang dilakukan ibuibu ini adalah PKK dengan pengelola utama adalah Ibu Tatik.

Hasil need assessment dengan kelompok PKK diperoleh beberapa permasalahan yang dirasakan kelompok ini meliputi 1) belum ada akses wifi sehingga kesulitan dalam membelajari anaknya di rumah, 2) kebutuhan akan skill/keterampilan seperti menjahit, merajut, memasak, daur ulang sampah; 3) pengenalan dan pengolahan Toga (tanaman obat keluarga); 4) pengolahan bahan pangan karena mereka tinggal di daerah wisata, sehingga kebutuhan akan kuliner meningkat; 5). Selama ini pelatihan yang pernah didapatkan adalah pengolahan makanan, namun hanya sekali dan belum ada tindak lanjutnya.

Pemberdayaan kelompok PKK sangat bermanfaat untuk meningkatkan ketahanan keluarga baik dari segi ekonomi, sosial, buadaya maupun agama. Berbagai keterampilan yang diperoleh, akan bisa membekali anggoatnya untuk bisa hidup lebih baik. PKK merupakan gerakan yang bersifat teksnis dalam program pemerintah berfokus pada pelaksanaan secara langsung di lapangan, pemberdayaan PKK bertujuan untuk meningkatkan kesejahteraan keluarga baik dari segi pengehatuan, informasi, kemandirian dalam pemenuhan kebutuhan hidup, dengan harapan dapat meningkatkan taraf hidup dan kondisi masyarakat yang lebih baik (Afriliya, 2017).

Kondisi pandemi Covid sangat membutuhkan daya imun yang cukup kuat untuk bisa menangkal virus Covid-19. Imunitas tubuh yang baik sangat diperlukan untuk membantu menghindari, mengatasi dan mempertahankan kesehatan selama masa Pandemi Covid-19, meningkatkan serta memelihara sistem imun agar dapat bekerja dengan optimal perlu dilakukan sedini mungkin melihat tingginya angka penyebaran Covid-19 yang mengancam kesehatan dan menjadi krisis global saat ini (Galmés et al., 2020). Pencegahan penyakit dan peningkatan kekebalan tubuh dapat dilakukan dengan mengkonsumsi tanaman herbal dan rempahrempah yang terbukti secara empiris dapat menjadi alternative pilihan terapi untuk mengatasi berbagai macam penyakit termasuk didalamnya infeksi virus, kandungan yang terdapat dalam tanaman herbal dan rempah- 
rempah memiliki efek yang baik untuk kesehatan bila dikonsumsi dengan cara dan ukuran yang tepat, penggunaan produk alami ini perlu dicanangkan sebagai salah satu cara pencegahan infeksi Covid-19 selama masa pandemic (Singh et al., 2021).

Maka keterampilan yang disepakati untuk diajarkan kepada ibu-ibu PKK adalah budidaya tanaman Toga. Tanaman obat keluarga atau yang lebih dikenal dengan Toga merupakan jenis tanaman yang memiliki kemudahan dalam proses pembudidayaan dan pemberdayaan, mulai dari penanaman yang dapat dilakukan di pekarangan rumah, kebun serta ladang dan memiliki manfaat untuk memenuhi kebutuhan keluarga akan pengobatan penyakit, estetika pada pekarangan rumah hingga meningkatkan ekonomi keluarga melalui hasil penjualan budidaya tanamanan Toga (Wirasisya et al., 2018). Toga telah terbukti secara ilmiah dapat digunakan untuk mengobati berbagai macam penyakit yang sering dialami oleh masyarakat (Lolita et al., 2017). Masyarakat dapat menanam, meramu, ataupun memperoleh TOGA secara mandiri tanpa bantuan tenaga medis. Hal ini menjadi alasan penting mengapa TOGA termasuk salah satu cara memandirikan masyarakat untuk mengatasi masalah, menjaga dan meningkatkan kesehatannya. Selain itu Toga bermanfaat untuk mengatasi berbagai macam penyakit yang biasa dialami oleh masyarakat (Nurjanah et al., 2019).

Berdasarkan permasalahan mitra di atas, maka solusi permasalahan yang disepakati Bersama antar pengsuul dengan pihak mitra PKK adalah:

1. Pengenalan macam-macam Toga dan manfaatnya

2. Tata cara budidaya Toga di rumah

3. Cara pengolahan Toga berbasis rumah tangga secara aman dan sehat

Luaran yang ditetapkan dari kegiatan ini adalah terlaksana program Toga PKK yang akan dijalankan setiap rumah tangga, dari yang sebelumnya tidak memiliki Toga menjadi memiliki minimal satu Toga. Kegiatan ini didukung oleh dosen Farmasi yang menekuni Toga, sehingga diharapkan program yang dijalankan lebih bisa merakyat dan diterima.

\section{METODE}

Kegiatan pengabdian dilakukan di desa Krebet, Bangunjiwo, Bantul, Yogyakarta pada 6 Februari 2021. Sasaran mitra adalah kelompok
PKK desa Krebet. Lokasi kegiatan di rumah ibu Dukuh dengan luas ruangan $6 \times 6 \mathrm{~m}$.

Kegiatan pengabdian masyarakat ini dilakukan dengan pemberian pendidikan kesehatan tentang Toga dan manfaatnya, serta tata cara budidaya Toga. Kegiatan berikutnya adalah praktek cara mengolah Toga (jahe) menjadi puding.

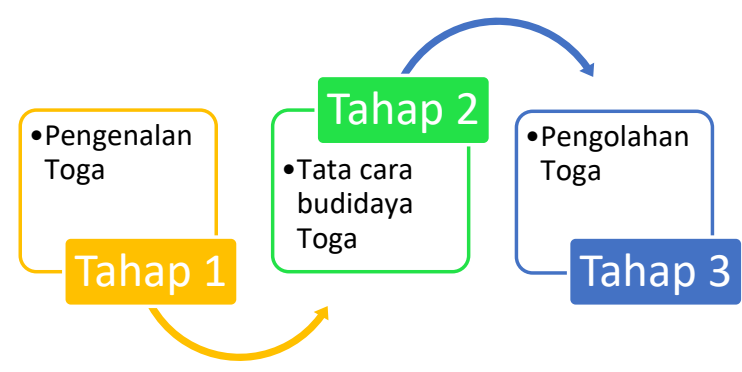

Gambar 2. Tahapan pelaksanaan pengabdian masyarkat

Partisipasi mitra dalam kegiatan pengabdian ini adalah menggerakkan anggota PKK untuk hadir dan berpartisipasi aktif, menyediakan tempat dan konsumsi. Keberlanjutan kegiatan ini akan dievaluasi melalui ketua penggerak PKK untuk melaporkan apakah anggota masih aktif dalam budidaya Toga, serta untuk kegiatan berikutnya adalah tata cara pengolahan Toga secara lebih variatif dan cara penyimpanan Toga agar tahan lama.

\section{HASIL DAN PEMBAHASAN}

Kegiatan pengabdian masyarakat ini berhasil dilaksanakan dalam tiga tahapan, yaitu pemberian pendidikan kesehatan tentang Toga dan manfaatnya (Gambar 3).

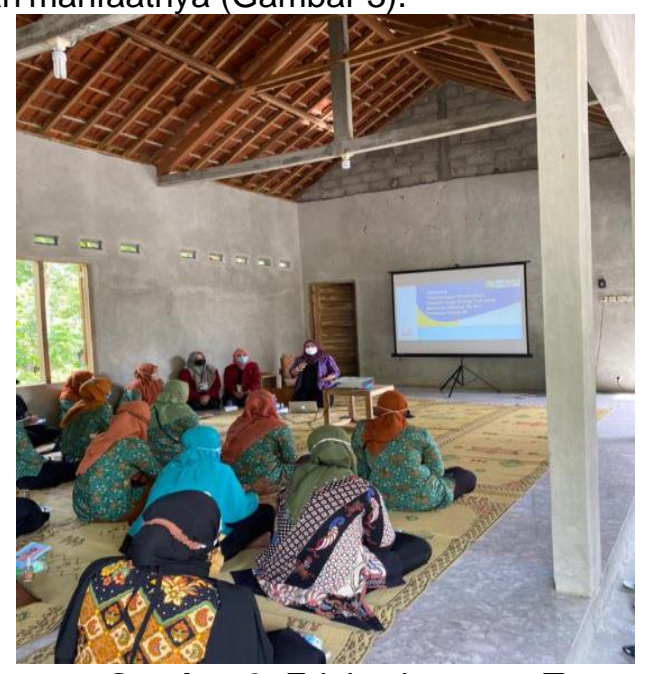

Gambar 3. Edukasi tentang Toga 
Acara selanjutnya yaitu simbolis penyerahan bibit Toga dan tata cara budidaya Toga (Gambar 4).

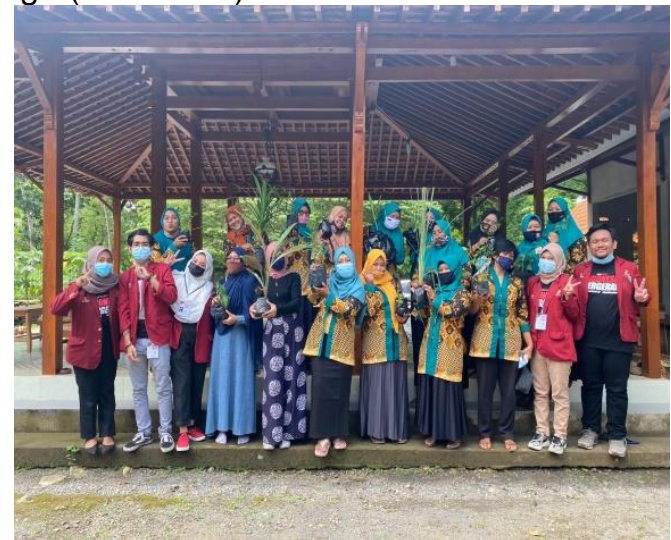

Gambar 4. Penyerahan dan penanaman Toga

Tahapan ketiga adalah praktek cara mengolah jahe menjadi puding (Gambar 5).

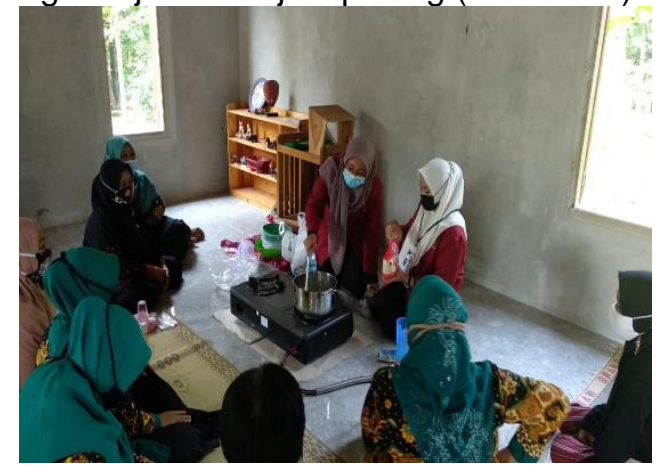

Gambar 5. Demo pembuatan pudding jahe

Kegiatan diikuti oleh 14 ibu-ibu peserta PKK. Mereka terlihat semangat dan antusias mengikuti seluruh rangkaian kegiatan. Hasil nilai post test menunjukkan peningkatan dari nilai pre test (Gambar 6).

\section{TREN PENINGKATAN \\ PENGETAHUAN}

nilai pre-test nilai post-test

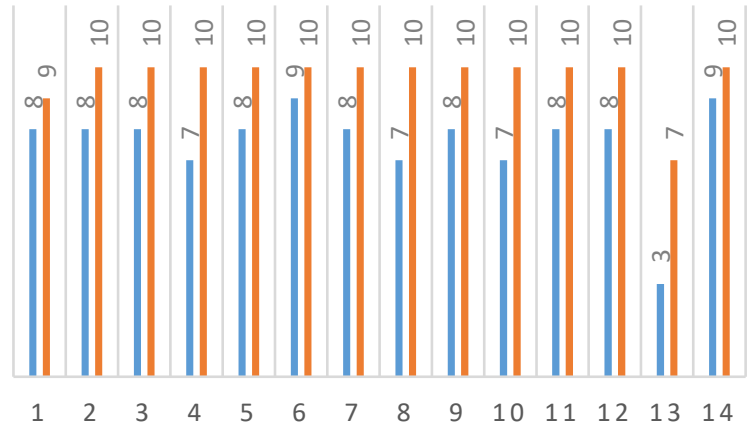

Gambar 6. Trend peningkatan nilai sebelum dan setelah pemberian pendidikan kesehatan
Gambar 6 menunjukkan hasil pre test tertinggi 9 dan terendah 3. Rata-rata nilai pre test adalah 7,57 . Hasil ini meningkat pada saat post test setelah dilakukan pendidikan kesehatan dengan nilai tertinggi 10 dan terendah 7. Rata-rata nilai post meningkat menjadi 9,71. Pendidikan kesehatan dapat mempengaruhi perilaku pengambilan keputusan, pencegahan penyakit dan kesadaran akan kesehatan yang dilakukan masyarakat (Bazaid et al., 2020). Sementara kurangnya informasi dan pengetahuan dapat menimbulkan persepsi negative seperti kecemasan, rasa takut dan khawatir ketika dihadapkan oleh penyakit. Pendidikan kesehatan menjadi solusi untuk mengatasi hal tersebut dengan cara meningkatkan pengetahuan untuk mengontrol serta mengambil tindakan atau treatment terbaik demi kesembuhan dan kesehatannya (Yuwono et al., 2017). Dalam pelaksanaan kegiatan, permasalahan yang dihadapi adalah tidak semua anggota PKK dapat mengikuti kegiatan karena PPKM, sehingga ruangan hanya bisa diisi $20 \%$ dari total anggota.

Data kemudian dilakukan uji statistic normalitas dan Wilcoxon dengan menggunakan aplikasi program statistic dan didapatkan hasil sebagai berikut (Tabel 1).

Tabel 1. Hasil uji Wilcoxon nilai pengetahuan sebelum dan setelah pemberian Pendidikan kesehatan

\begin{tabular}{ll}
\hline Variabel & $\mathrm{P}$ value \\
\hline Pre test & 0,001 \\
Post test & \\
\hline
\end{tabular}

Hasil uji normalitas diperoleh nilai signifikansi $p=0,000$ artinya data tidak terdistribusi normal. Dilanjutkan dengan uji statistik Wilcoxon diperoleh nilai $\mathrm{p}=0,001$ $(<0,05)$, yang bermakna bahwa pendidikan kesehatan tentang Toga memiliki pengaruh signifikan terhadap peningkatan pengetahuan peserta akan manfaat tanaman obat keluarga. Upaya peningkatan pengetahuan terkait tanaman obat keluarga Toga merupakan salah satu program dibidang kesehatan yang dapat memberikan manfaat secara langsung seperti peningkatan literasi, pengetahuan, keterampilan budi daya Toga dan pemanfaatan Toga sebagai sumber pendapatan tambahan untuk meningkatkan ekonomi keluarga (Yudhapramesti et al., 2019).

Pendidikan kesehatan tanaman obat keluarga merupakan upaya meningkatkan pengetahuan masyarakat melalui pembelajaran, dimana pendidikan kesehatan telah terbukti meningkatkan pengetahuan masyarakat secara signifikan terkait Toga. Pre test dan post test dibutuhkan untuk mendapatkan gambaran 
sejauh mana pemahaman masyarakat terkait Toga, dan membantu dalam pemilihan level pemberian informasi seperti pengetahuan dasar ataupun kedalaman materi Toga (Lolita et al., 2017). Pendidikan kesehatan ataupun pelatihan tanaman obat keluarga dapat meningkatkan pengetahuan, sikap dan keterampilan masyarakat dalam penggunaan TOGA seperti ketepatan takaran atau dosis, pemilihan bahan, waktu dan cara penggunaan, harapannya masyarakat dapat lebih kritis dan rasional selama penggunaan Toga untuk menghindari hal-hal yang tidak diinginkan (Choironi et al., 2019).

\section{SIMPULAN DAN SARAN}

Kegiatan pengabdian masyarakat diikuti oleh 14 peserta. Rangkaian kegiatan yang dilakukan yaitu pemberian pendidikan kesehatan tentang Toga dan manfaatnya, tata cara budidaya Toga, serta praktek cara mengolah Toga menjadi pudding jahe. Hasil evaluasi menunjukkan terjadi peningkatan pengetahuan peserta sebelum dan setelah pemberian pendidikan kesehatan.

\section{UCAPAN TERIMAKASIH}

Ucapan terimakasih pengabdi haturkan kepada pihak LP3M Universitas Muhammadiyah Yogyakarta sebagai pemberi hibah dana pengabdian masyarakat sehingga kegiatan ini dapat terlaksana dengan lancar.

\section{DAFTAR RUJUKAN}

Afriliya, A. (2017). Penerapan program pemberdayaan dan kesejahteraan Keluarga (PKK) (Studi tentang modal sosial pada pelaksanaan bidang kesehatan,pendidikan dan keterampilan program PKK Kelurahan Simpang Baru Kecamatan Tampan Kota Pekanbaru). JOM FiSIP, 4(2), 115.

https://media.neliti.com/media/publicati ons/183768-ID-partisipasi-masyarakatdalam-pelaksanaan.pdf

Bazaid, A. S., Aldarhami, A., Binsaleh, N. K., Sherwani, S., \& Althomali, O. W. (2020). Knowledge and practice of personal protective measures during the COVID19 pandemic: A cross-sectional study in Saudi Arabia. PLoS ONE, 1-15. https://doi.org/10.1371/journal.pone.02 43695

Choironi, N. A., Wulandari, M., \& Susilowati, S. S. (2019). Pengaruh edukasi terhadap pemanfaatan dan peningkatan produktivitas tanaman obat keluarga (TOGA) sebagai minuman herbal instan di Desa Ketenger Baturraden.
Kartika: Jurnal IImiah Farmasi, 6(1), 1. https://doi.org/10.26874/kjif.v6i1.115

Galmés, S., Serra, F., \& Palou, A. (2020). Current state of evidence: Influence of nutritional and nutrigenetic factors on immunity in the COVID-19 pandemic framework. Nutrients, 12, 1-33. https://doi.org/10.3390/nu12092738

Kurniawan, A., \& Sadali, M. I. (2018). Keistimewaan Lingkungan Daerah Istimewa Yogyakarta. Gadjah Mada University Press.

Lolita, Rahmawati, A., Rahmah, A., Hasan, E. A., Afra, F. Y., \& Ikrimah. (2017). Pengaruh promosi kesehatan terhadap pengetahuan Toga untuk hipertensi di Sumberagung Jetis Bantul. Pharmacy, 14(02), 236-246.

Nurjanah, S. R., Nurazizah, N. N., Septiana, F., \& Shalikhah, N. D. (2019). Peningkatan kesehatan masyarakat melalui pemberdayaan wanita dalam pemanfaatan lahan Pekarangan dengan tanaman obat keluarga (TOGA). Community Empowerment, 4(1), 20-25. https://doi.org/10.33084/pengabdianm u.v2i2.63

Pemerintah Kabupaten Bantul. (2021). Kapanewon Pajangan.

Rahmawati, R., \& Purwohandoyo, J. (2019). Perkembangan desa wisata Krebet dan dampaknya terhadap kondisi ekonomi masyarakat dusun Krebet, desa Sendangsari, kecamatan Pajangan, kabupaten Bantul. Jurnal Geografi, 11(1), 62-67. http://jurnal.unimed.ac.id/2012/index.p $\mathrm{hp} / \mathrm{geo}$

Singh, N. A., Kumar, P., Jyoti, \& Kumar, N. (2021). Spices and herbs: Potential antiviral preventives and immunity boosters during COVID-19. Phytotherapy Research, 1-13. https://doi.org/10.1002/ptr.7019

Wirasisya, D. G., Juliantoni, Y., \& Alqadri, B. (2018). Peningkatan kesehatan masyarakat melalui sosialisasi Penggunaan TOGA (Tanaman Obat Keluarga) Di Desa Tembobor. Sarwahita, 15(1), 64-71. https://doi.org/10.21009/sarwahita.151. 07

Yudhapramesti, P., Srimulyani, H., \& Zulfan, I. (2019). Dinamika Proses Komunikasi Dan Transfer Informasi Kesehatan Pada Pengelolaan Taman Toga. Interaksi: Jurnal IImu Komunikasi, 8(1), 43-54.

https://doi.org/10.14710/interaksi.8.1.4 3-54 
Yuwono, G. A., Ridwan, M., \& Hanafi, M. (2017). Pengaruh pendidikan kesehatan tentang hipertensi terhadap tingkat kecemasan pada penederita hipertensi di kabupaten Magelang. Jurnal Keperawatan Soedirman, 12(1), 55-66. https://doi.org/10.15900/j.cnki.zylf1995. 2018.02.001 